\title{
Climatology of Iraqi dust events during 1980-2015
}

\author{
Ali. A. Attiya ${ }^{1,2} \cdot$ Brian G. Jones ${ }^{2}$ (I)
}

Received: 15 November 2019 / Accepted: 1 April 2020 / Published online: 7 April 2020

(c) Springer Nature Switzerland AG 2020

\begin{abstract}
Mesopotamia in Iraq is exposed to dust events of different intensity because of adjacent extended desert or semi-desert areas. This study investigates the spatial-temporal distributions of dust events (including suspended dust, rising dust and dust storms) in Iraq by analysing dust observations based on visibility from seven meteorological stations supplied by the Iraqi Meteorological Organization (IMO) during 1980-2015. The annual and seasonal evaluation of all dust event frequencies is examined. The findings show that Iraq has been exposed to the maximum number of dust events in spring and summer seasons over the past 35 years. The dust was more active in summer compared with other seasons for the northern region of Iraq, while the south and central parts of Iraq are exposed to the largest frequency of dust storms in spring and summer. The cities near desert areas (e.g. Nasiriya, Basra and Baghdad) suffer from the greatest frequency of dust storms compared to the northern and eastern regions. According to the annual average during 1980-2015, the frequency of major dust storm activity in Nasiriya was 7.8 days, in Baghdad 3.1 days) and in Basra 2.3 days. Suspended dust is more frequent in Iraq compared with rising dust or dust storms. There was a greater frequency of dust events associated with high temperatures and wind speeds in the central and southern areas during summer. All three types of dust events show similar time trend distributions with three periods: increased frequency of dust between 1980 and 1993, decreased frequency during 1993-2001 and increased again from 2001.
\end{abstract}

Keywords Dust events $\cdot$ Suspended dust $\cdot$ Rising dust $\cdot$ Dust storms $\cdot$ Temperature $\cdot$ Wind speed

\section{Introduction}

Dust events generated from dry and semi-dry areas in the globe have serious effects on public health, climate and the economy. Dust events represent one of the most common phenomena that lead to weather, ecosystem, public health and economic problems in the world [1-5]. For example, transported dust from the Sahara has impacted soils on Mount Cameroon and in the Canary Islands [6, 7]. The USA Dust Bowl disaster caused significant economic damage and environmental disaster which impacted on farmers in North America in 1930s [8]. Dust storms affect agriculture, transportation and health sectors in Iraq and Iran which caused damages of approximately 1404 and 1043.5 million dollars in 2013, respectively [9]. The main sources of dust in the world are located in low lands in dry areas with decreased vegetation, regions with an annual average rainfall of less than $200 \mathrm{~mm}$ and alluvial plains $[10,11]$. These constitute $33 \%$ of the global land region, especially in Mongolia, the Middle East and North African deserts. Dust events in the Asian region, the Middle East and Sahara are estimated to produce from 200 to 5000 million tons of dust annually [12]. The complicated interaction processes between soil properties, atmospheric circulation and regional/local meteorological conditions are termed aeolian erosion [13, 14]. Arid areas in central and southwestsouth-west Asia have a high probability to emit dust $[10,15]$. After long periods of drought, the vegetation coverage becomes very low in the region, therefore, leading to aeolian erosion causing mobilization of dust and

$\triangle$ Ali. A. Attiya, aaa800@uowmail.edu.au | ${ }^{1}$ Atmospheric Science Department, Science Faculty, Mustansiriya University, Baghdad, Iraq. ${ }^{2}$ School of Earth, Atmospheric and Life Sciences, University of Wollongong, Wollongong, NSW 2522, Australia. 
producing strong dust events [16-18]. These dust events have impacts on humans who live in the dry and semi-dry regions, as well as transport the dust for long distances that can influence the climate away from the sources of dust. Therefore, examining the variation of dust events is considered an important factor when considering the air quality, weather, economy and health. Dust storms can transport a range of pollutants, such as pesticides, heavy metals, particulate matter (PM10 with diameters $<10 \mu \mathrm{m}$, and PM2.5 with diameters less than $2.5 \mu \mathrm{m}$ ), biological components (bacteria, fungi and spores), potential allergens and gases, over thousands of kilometers from the main sources of dust such as the western USA, Middle East, eastern and central Asia and North Africa. Particulate matter loadings can far exceed global health standards and cause human health implications during dust storms, such as injuries and deaths related to transport accidents, skin irritation, conjunctivitis, meningococcal meningitis, and cardiovascular complaints [3]. Exposure to fine desert dust particles can lead to respiratory problems, e.g. desert lung syndrome as well as chronic obstructive pulmonary emphysema, bronchitis, asthma, and dermatological disorders [19].

In the last few years, most regions of central-southwest Asia have been exposed to a significant rise in dust intensity and occurrence $[18,20]$. Annually, particularly in summer and spring months, massive amounts of dust aerosols originate from the dry and semi-dry areas of southwest and middle parts of Asia and are transferred by winds for thousands of kilometers over different regions such as the Japan Sea [21], China [22], the Arabian Sea and the central Asia [23]. Dust event analysis and studies have used traditional surface weather datasets to analyse the types of dust activity. Some researchers have used statistical analysis to evaluate the seasonal variability and frequency of dust events over dry and semi-dry areas in Asia [17, 22, 24-27]. A study by Furman [24] examined the dust sources and dust temporal properties in the Middle East, which is one of the areas most impacted by dust after the North Africa region. His results found that dust events are recurrent during the year, while the highest dust activity period varies in different Middle East areas. These dust events are more frequent in spring and winter in the northwestern Middle East, while they reach maximum activity during summer months in the southwest of this region. Dust events over the Middle East were examined and showed that a large frequency of dust events is seen in Iraq and Saudi Arabia associated with predominant northeast and northwest winds, while those in Afghanistan and Iran are associated with northwest winds (called 120-day winds). Dust events have different seasonal distribution in various areas of the Middle East. In the western Middle East, dust episodes are more frequent in winter while in the eastern
Middle East, dust episodes are more frequent in summer [28]. Mashat et al. [29] recorded that annual mean number of dust events was 24.6 in southwestern Saudi Arabia, with higher average numbers of dust days in June (29.25), July (29.96) and August (30.16). Pi et al. [27] indicated considerable spatial variability of dust storm frequencies in the Xinjiang Province in northwest China, where the annual mean number of dusty days was 111.3 in the south and 10.9 in the north. Pokharel and Kaplan [30] analysed dust events at the NASA DFRC in Lancaster, California, USA during the 15 years. The results showed the maximum percentage of the dust activity was during autumn (44.7\%) and spring $(38.3 \%)$ while the minimum percentage of the dust activity was during summer $(8.5 \%)$ and winter (8.5\%).

Aerosol Index (Al) values from TOMS (Total Ozone Mapping Spectrometer platform) satellite data were plotted to analyse the spatiotemporal distribution of dust events and identify main source areas of desert dust in the world [11]. TOMS satellite observations showed that the central and southern parts of Iraq have higher Al values from May to June, while lower Al values were recorded in the northern region in winter [31]. The World Meteorology Organization (WMO) has classified dust events based on visibility into four dust types: (1) Dust haze (suspended dust) when the horizontal visibility more than $10 \mathrm{~km}$; (2) Blowing dust (rising dust) with horizontal visibility from 1 to $10 \mathrm{~km}$; (3) Dust storms when horizontal visibility is between $200 \mathrm{~m}$ and $1 \mathrm{~km}$; and (4) Severe dust storms when horizontal visibility less than $200 \mathrm{~m}[32,33]$. The codes for these dust types used by WMO are displayed in Table 1. Studies of dust events have widely used the traditional surface weather station datasets to analyse types of dust activity [27, 28, 33, 34]. Despite the Middle East being considered a significant source of dust, few studies have analysed various dust types for this area. The objective of the study is to investigate of dust event variability which represents an important factor when considering air quality, climate change, economy and health. The study by Varoujan et al. [35] showed Iraq is exposed to numerous dust events annually based on reports from the Iraqi Environment Ministry which documented 122 extreme dust storms and 283 dusty days through the year. Thus, the climatological analysis of dust events in this region is a subject of increasing interest. This study aims to analyse the spatial-temporal variability of dust event types (suspended dust, rising dust and dust storms), to get a better understanding and knowledge about spatial-temporal variability of dust events based on 35 years of ground observations from seven meteorological stations over Iraq that identifies the dominant dust type. The present work concludes by considering if there is any difference in the spatiotemporal distribution of dust events between surface stations. This study will be useful to researchers in 
Table 1 Showing synoptic weather codes of dust events applied in the present study

\begin{tabular}{ll}
\hline WMO-codes & Description of synoptic weather codes \\
\hline 06 & Widespread dust in suspension in the air, raised by wind at or near the station at the time of observation \\
07 & $\begin{array}{c}\text { Dust or sand raised by wind at or near the station at the time of observation, but no well-developed dust } \\
\text { whirl(s) and no dust storms or sandstorms observed }\end{array}$ \\
09 & Dust storm or sandstorm within sight at the time of observation or at the station during the preceding hour \\
30 & Slight or moderate dust storm or sandstorm has decreased during the preceding hour \\
31 & Slight or moderate dust storm or sandstorm with no appreciable changes during the preceding hour \\
32 & Slight or moderate dust storm or sandstorm has begun or has increased during the preceding hour \\
33 & Severe dust storm or sandstorm has decreased during the preceding hour \\
34 & Severe dust storm or sandstorm with no appreciable changes during the preceding hour \\
35 & Severe dust storm or sandstorm has begun or has increased during the preceding hour
\end{tabular}

the environment and climate sector to reduce and combat atmospheric dust activity in the future.

\section{The study site}

The Iraq study region, located in southwestern Asia covers most of Mesopotamia, extending between $29^{\circ}-37^{\circ} \mathrm{N}$ and $38^{\circ}-48^{\circ} \mathrm{E}$. The study region is bordered by the Syrian and Jordan deserts in the west, Kuwait and Saudi Arabian deserts in the south, the Persian Gulf in the southeast, arid areas of Iran in the east and arid regions of Turkey in the north. The topography of Iraq includes the alluvial plains in the Euphrates and Tigris Basin. The alluvial plains are surrounded to the south and west by arid lands that occupy approximately $40 \%$ of total area of Iraq, and to the north and east by mountain chains that exceeds $3550 \mathrm{~m}$ in height [36]. Snow cover frequently forms during the winter in the mountain regions. It may cause extensive floods as it melts in spring. The Arabian Peninsula in the Middle East is characterised by large deserts that occupy an area of around 2,330,000 square kilometers. These deserts extended from Syria and Jordan to Oman and from the Persian Gulf to Yemen. Rub'al-Khali Desert represents one of the large deserts at a global scale and is attached to the An-Nafud Desert in northern Arabia via the Ad-Dahna Desert in the east part of Arabia [32]. The climate of Iraq can be characterized as hot in summer (temperature mean $40^{\circ} \mathrm{C}$ and can exceed $48^{\circ} \mathrm{C}$ ). It is an arid subtropical environment, with an annual mean of precipitation of $250 \mathrm{~mm}$ in winter while precipitation is very rare in the summer season. The relative humidity $(\mathrm{RH} \%)$ value is low in Iraq, in the north ranging from 22.9 to $28.1 \%$, in centre from 23.8 to $28.6 \%$ and in the southern regions from 20.6 to $25.3 \%$ [31].

Iraq has a largely arid and semi-arid landscape and as a result is a significant producer of dust, while, in addition, it is known that dust from adjoining territories, including
North Africa are transported to Iraq. Due to the different climates in Iraq, various regions in Iraq were chosen for a thorough analysis of the different types of dust and the frequency of dust events. The meteorological observations between 1980 and 2015 utilized for the dust event type analysis have been taken from seven weather stations situated in five parts of Iraq (Fig. 1). Weather stations in the northern part are located in Mosul and Kirkuk. The central weather station is located in Baghdad, an eastern weather station is located in Khanaqin and in the west the weather station is located in Rutba. In southern Iraq weather stations are located in Nasiriyah and Basra.

\section{Methods and data collection}

The weather stations are a significant source of ground observations to assess dust events, because these stations normally supply hourly or three hourly meteorological data and visibility ranges. Many kinds of research have employed visibility measurements to evaluate dust events in southwestern Asia and the Middle East [23, 28, 29, 32-34, 37].

Dust observations (frequency of suspended dust, rising dust and dust storms) have been collected from the Iraqi Meteorological Organization and these data were utilized to determine the annual and seasonal mean frequency of dust events in Iraq. Meteorological data [temperatures (Temp) and wind speeds (WS)] were also collected. These observations have been collected from the seven ground meteorological stations in Iraq (Fig. 1) between 1980 and 2015. Datasets from other weather stations in Iraq are too incomplete for use in this study. The seasonal mean frequency for each station was calculated by taking the monthly average frequency of all dust types during the 35 years, then taking the mean of three months for each season (December, January and February for winter, March, April and May for 


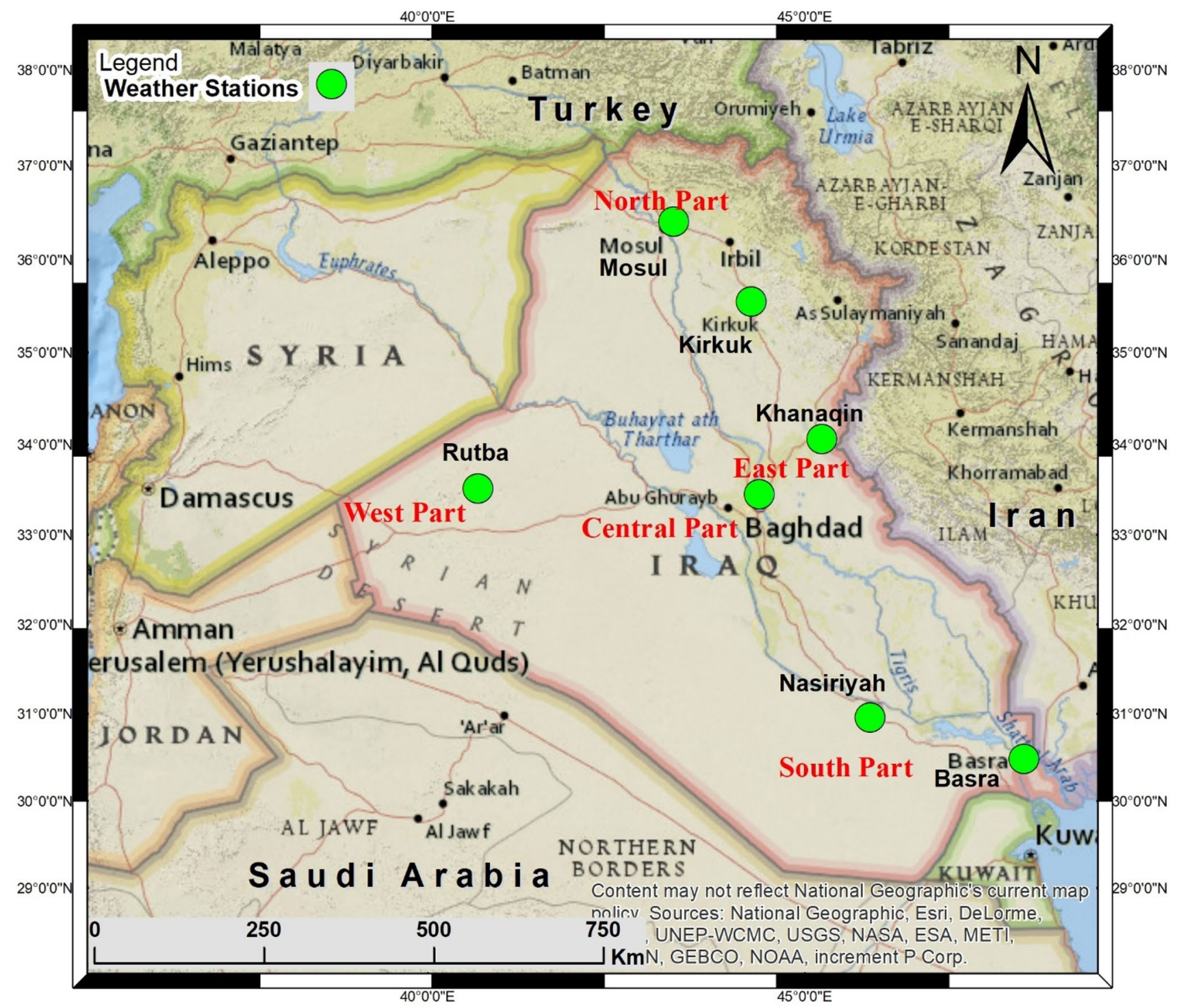

Fig. 1 The spatial distribution weather stations used for monitoring dust events in Iraq. Source: ESRI online database and ArcGIS 10.4 analytic tools, and the Iraqi meteorological weather station locations from the Iraqi Meteorological Organization (IMO)

spring, June, July and August for summer and September, October and November for autumn). The total frequency was calculated by summation of the frequency of each dust type during 1980-2015. The annual mean frequency of all dust events was calculated by taking the mean of the monthly average frequency of all dust types during the study period. The mechanisms of dust events classification can be changed from one area to another [34]. The synoptic weather codes of dust events according to WMO are shown in Table 1. In the present study, dust events were divided by the Iraqi Meteorological Organization (IMO) into three types: suspended dust (SD), which has a 06 WMO code; rising dust (RD), which has 07 a WMO code; and dust storms (SD), which include both dust storm and severe dust storm observations that have WMO codes $(09,30,31,32)$ and $(33,34$, $35)$, respectively.

The monthly average of temperatures and wind speeds were calculated by taking the daily average during 1980-2015. These monthly meteorological elements from the selected stations were plotted on a map utilizing an Arc GIS program to explain its spatial distribution. 


\section{Results}

\subsection{Spatial variability of the frequency of each dust type}

Figure 2 displays the spatial variability of the annual mean frequency of the three dust events. The dust occurrence is high in the southern and central regions around Nasiriyah, Basra and Baghdad followed by the Mosul region adjacent to the Syrian Desert. The eastern region (Khanaqin) has the lowest annual mean frequency of dust events.
The total frequency of the three dust events (suspended dust, rising dust and dust storms) is plotted in Fig. 3a-c that displays the total frequency of suspended dust, rising dust and dust storms, respectively, for the period 1980-2015. It is obvious that the highest total frequency of suspended dust (SD) was recorded in Nasiriya in the southern region probably because of the nearby southern and western deserts in Iraq and the Saudi Arabian deserts to the southwest of Iraq (Fig. 3a). This is followed by Baghdad, which is near the Western Desert. Mosul and Kirkuk in the northern region also recorded large frequencies of suspended dust events may be because of their location close to desert areas in Syria. Khanaqin in the eastern region had relatively low levels

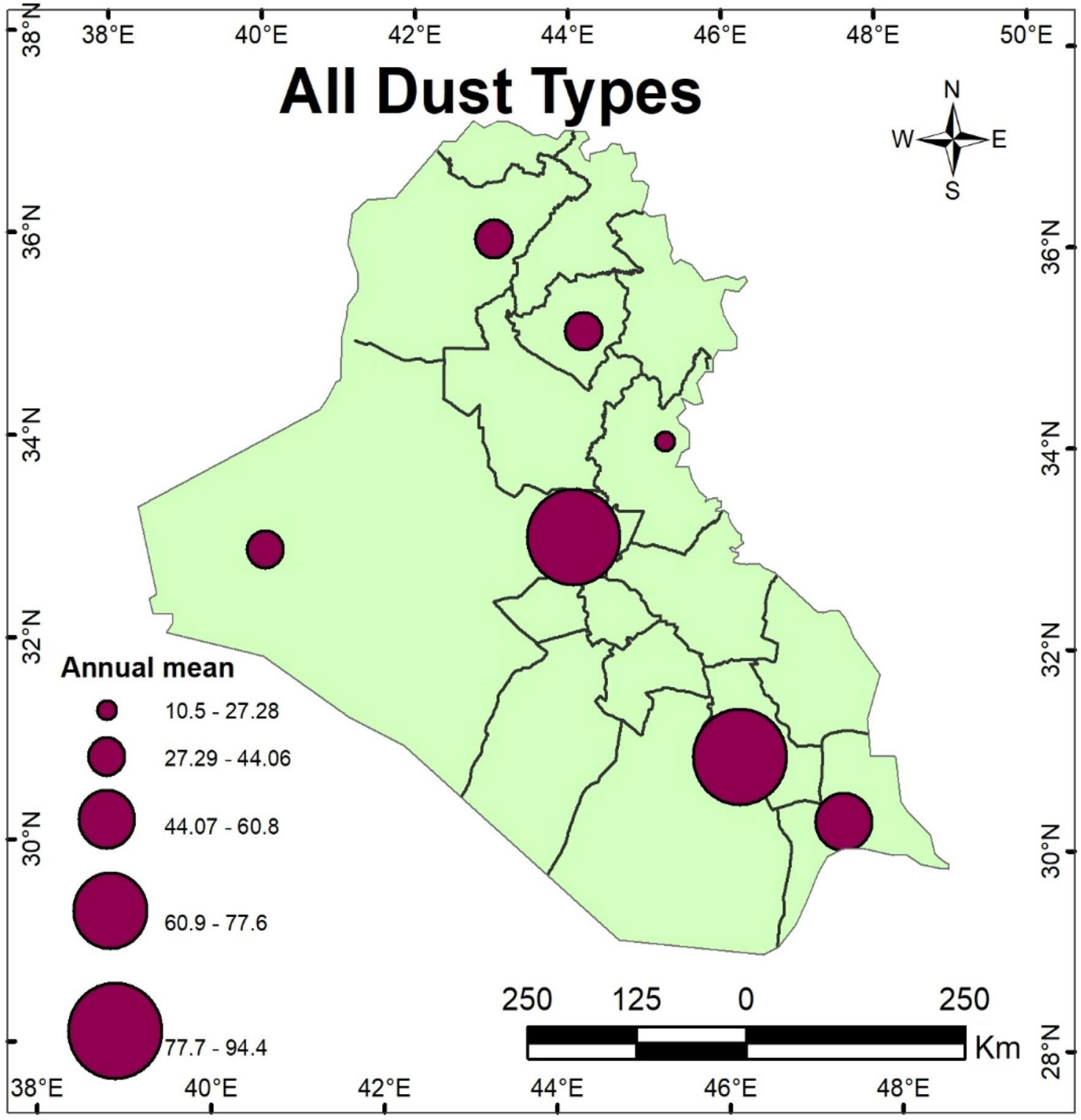

Fig. 2 The annual mean frequency of all dust events during 1980-2015 in Iraq 




Fig. 3 The total frequency (in days) of dust events over chosen stations in Iraq during 1980-2015: a suspended dust, b rising dust and c dust storms

of suspended dust events. This may be attributed to the location of Khanaqin because this city is situated away from the deserts and semi-deserts in Iraq.

The highest frequency of rising dust (RD) occurred in the southern cities (Nasiriya and Basra) close to the main Western Desert dust source (Fig. 3b). In this case, the frequency of rising dust days in the west and central areas are lower than in the southern area. The overall frequency of rising dust events reduced gradually across the northern cities and declined further in the eastern region. The minimum total frequency of rising dust was observed in Khanaqin.

Figure $3 \mathrm{c}$ shows that the southern and central areas are exposed to a higher frequency of dust storms (DS) than the other parts of Iraq that are more remote from the main dust sources in Syria and Saudi Arabia. The eastern area had some dust storms, however, not as many as the southern and central areas. The lowest frequency of dust storms was observed in the northern (Kirkuk and Mosul) and eastern (Khanaqin) regions. When comparing the three kinds of dust events, suspended dust happens most often whereas dust storms happened the least during the study period. It is obvious that the spatial patterns of annual mean dust events were most like the total frequency of suspended dust since it is the dominant kind of dust activity in Iraq.

\subsection{Spatial distribution of seasonal mean dust types in Iraq}

The dust observations from the seven cities were plotted as dot maps utilizing the ArcGIS program to show the spatial distribution of dust events seasonally above Iraq during the study period (1980-2015; Fig. 4). This figure illustrates seasonal spatial variations of dust events with maximum average frequency of dust being in spring and summer months.

The spatial patterns of the mean frequency of all dust events in the winter season are given in Fig. 4a. The maximum mean of dust frequency is observed above the southern part of Iraq while the minimum mean record was in the northern and western regions. Figure $4 \mathrm{~b}$ displays the spatial patterns of the mean frequency of all dust events during the spring season that still reveals the highest frequency of dust events in the southern area. In comparison to the winter season, dust events started to increase in spring throughout Iraq, but particularly in the central and southern regions of Iraq.

Figure 4c shows that the highest average frequency of all dust events in the summer season occurs in the southern region with this increased frequency spreading to the central regions of Iraq. The average frequency of dust activity was still low in parts of the northern and eastern regions. The spatial variability of the mean frequency of dust events during the autumn season can be seen from Fig. $4 \mathrm{~d}$. The maximum average frequency of all dust events was recorded in the southern region with an increased frequency of dust spreading across the central and northern areas. In eastern Iraq, Khanaqin has a low frequency of dust events through the autumn months.

The dust events are also examined by kind and season for each selected city and area recorded above. The 




Fig. 4 Seasonal mean frequency (in days) of all dust types in Iraq (1980-2015)

Table 2 The seasonal-annual average number of suspended dust days in Mosul and Kirkuk

\begin{tabular}{lcllll}
\hline City & Spring season & Summer season & $\begin{array}{l}\text { Autumn } \\
\text { season }\end{array}$ & Winter season & Annual average \\
\hline Mosul & 8.5 & 16.6 & 9.5 & 2.9 & 37.5 \\
Kirkuk & 10.1 & 11.9 & 6.5 & 2.7 & 31.3 \\
Region average & 9.3 & 14.3 & 8.0 & 2.8 & 34.4 \\
\hline
\end{tabular}

seasonal and annual mean frequency of dust activity for 
Table 3 The seasonal-annual average number of rising dust days in Mosul and Kirkuk

Table 4 The seasonal-annual average number of dust storm days in Mosul and Kirkuk

Table 5 The seasonal-annual average number of suspended dust days in Baghdad, Rutba and Khanaqin

Table 6 The seasonal-annual average number of rising dust in Baghdad, Rutba and Khanaqin

Table 7 The seasonal-annual average number of dust storm days in Baghdad, Rutba and Khanaqin

Table 8 The seasonal-annual average number of suspended dust days in Nasiriya and Basra

\begin{tabular}{llllll}
\hline City & Spring season & $\begin{array}{l}\text { Summer } \\
\text { season }\end{array}$ & $\begin{array}{l}\text { Autumn } \\
\text { season }\end{array}$ & Winter season & $\begin{array}{l}\text { Annual } \\
\text { aver- } \\
\text { age }\end{array}$ \\
\hline Mosul & 2.1 & 1.8 & 1.0 & 0.3 & 5.2 \\
Kirkuk & 2.4 & 1.3 & 0.7 & 0.5 & 4.9 \\
Region average & 2.2 & 1.6 & 0.9 & 0.4 & 5.1 \\
\hline
\end{tabular}

\begin{tabular}{llllll}
\hline City & Spring season & $\begin{array}{l}\text { Summer } \\
\text { season }\end{array}$ & $\begin{array}{l}\text { Autumn } \\
\text { season }\end{array}$ & Winter season & $\begin{array}{l}\text { Annual } \\
\text { aver- } \\
\text { age }\end{array}$ \\
\hline Mosul & 0.2 & 0.1 & 0.2 & 0.0 & 0.6 \\
Kirkuk & 0.3 & 0.2 & 0.2 & 0.1 & 0.7 \\
Region average & 0.2 & 0.1 & 0.2 & 0.1 & 0.6 \\
\hline
\end{tabular}

\begin{tabular}{lccccc}
\hline City & Spring season & Summer season & Autumn season & Winter season & Annual average \\
\hline Khanaqin & 2.7 & 2.7 & 1.2 & 0.6 & 7.2 \\
Baghdad & 16.1 & 21.1 & 13.6 & 8.1 & 58.9 \\
Rutba & 5.3 & 3.1 & 3.3 & 1.4 & 13.1 \\
Region average & 8.0 & 9.0 & 6.0 & 3.4 & 26.4 \\
\hline
\end{tabular}

\begin{tabular}{lllllc}
\hline City & Spring season & $\begin{array}{l}\text { Summer } \\
\text { season }\end{array}$ & $\begin{array}{l}\text { Autumn } \\
\text { season }\end{array}$ & Winter season & Annual average \\
\hline Khanaqin & 1.4 & 0.8 & 0.5 & 0.3 & 3.0 \\
Baghdad & 5.9 & 9.5 & 2.7 & 2.4 & 20.4 \\
Rutba & 6.5 & 3.8 & 2.8 & 2.7 & 15.8 \\
Region average & 4.6 & 4.7 & 2.0 & 1.8 & 13.1 \\
\hline
\end{tabular}

\begin{tabular}{llllll}
\hline City & Spring season & $\begin{array}{l}\text { Summer } \\
\text { season }\end{array}$ & $\begin{array}{l}\text { Autumn } \\
\text { season }\end{array}$ & Winter season & $\begin{array}{l}\text { Annual } \\
\text { average }\end{array}$ \\
\hline Khanaqin & 0.2 & 0.0 & 0.0 & 0.0 & 0.3 \\
Baghdad & 1.3 & 1.1 & 0.3 & 0.5 & 3.1 \\
Rutba & 0.9 & 0.3 & 0.2 & 0.3 & 1.7 \\
Region average & 0.8 & 0.5 & 0.2 & 0.3 & 1.7 \\
\hline
\end{tabular}

\begin{tabular}{lcllll}
\hline City & Spring season & Summer season & $\begin{array}{l}\text { Autumn } \\
\text { season }\end{array}$ & Winter season & Annual average \\
\hline Nasiriya & 12.9 & 18.5 & 9.3 & 5.4 & 46.1 \\
Basra & 7.8 & 10.5 & 4.4 & 2.2 & 24.9 \\
Region average & 10.4 & 14.5 & 6.8 & 3.8 & 35.5 \\
\hline
\end{tabular}

\section{SN Applied Sciences}


Table 9 The seasonal-annual average number of rising dust days in Nasiriya and Basra

\begin{tabular}{lcclll}
\hline City & Spring season & Summer season & $\begin{array}{l}\text { Autumn } \\
\text { season }\end{array}$ & Winter season & Annual average \\
\hline Nasiriya & 11.3 & 18.1 & 7.1 & 4.0 & 40.5 \\
Basra & 5.6 & 9.8 & 2.7 & 1.7 & 19.8 \\
Region average & 8.5 & 14.0 & 4.9 & 2.9 & 30.2 \\
\hline
\end{tabular}

\begin{tabular}{llllll}
\hline City & Spring season & $\begin{array}{l}\text { Summer } \\
\text { season }\end{array}$ & $\begin{array}{l}\text { Autumn } \\
\text { season }\end{array}$ & Winter season & $\begin{array}{l}\text { Annual } \\
\text { aver- } \\
\text { age }\end{array}$ \\
\hline Nasiriya & 2.1 & 4.6 & 0.6 & 0.5 & 7.8 \\
Basra & 0.7 & 1.1 & 0.3 & 0.2 & 2.3 \\
Region average & 1.4 & 2.9 & 0.5 & 0.3 & 5.0 \\
\hline
\end{tabular}

Table 10 The seasonal-annual average number of dust storm days in Nasiriya and Basra mean of 2.2 days for both Mosul and Kirkuk. The minimum regional average was in winter, but it did not vary much from that in autumn. Kirkuk had the highest rising dust frequency during spring (about 2.4 days), whereas during summer the rising dust frequency for Mosul and Kirkuk were around 1.8 and 1.3 days, respectively.

Table 4 displays the average frequency of dust storms in northern Iraq for all seasons. Kirkuk has the highest mean dust storm frequency ( 0.3 days) in spring compared to Mosul with about 0.2 days. The highest dust storm activity happens in Kirkuk during the summer (0.2 days), while in Mosul it is around 0.1 days. Kirkuk and Mosul had similar dust storm frequencies ( 0.2 days) in autumn. There was no dust storm activity in Mosul during winter, while in Kirkuk it occurred on around 0.1 days. The highest regional average was about 0.2 days during the autumn and spring seasons. Kirkuk had a higher of annual average frequency of dust storms on 0.7 days compared with frequency of 0.6 days in Mosul. Kirkuk and Mosul suffered from more dust activity during spring and autumn seasons during the 35 years of study.

Generally, Table 4 illustrates that the northern region in Iraq was not exposed to as many severe dust storms during the study period compared with other regions. The annual average frequency of dust storms in the northern area is 0.6 days.

\subsection{Central, western and eastern Iraq}

Dust observations from three ground meteorological stations (Table 5) have been examined and analysed to document dust events over central (Baghdad), western (Rutba) and eastern (Khanaqin) Iraq. The western area is characterized by an arid (desert) region that differs from the other parts. This variance of terrain can influence dust activity, particularly suspended and rising dust events. 
Baghdad clearly had the highest frequency of suspended dust activity during summer (about 21.1 days), followed by Rutba ( 5.3 days in spring), with annual mean frequency of suspended dust in the two cities of 58.9 and 13.1 days, respectively. During the winter season Rutba and Khanaqin had the lowest mean frequency of suspended dust activity on 1.4 and 0.6 days, respectively. The highest regional mean frequency of suspended dust activity (9.0 days) was during the summer, while the lowest dust activity (3.4 days) was during winter. In general, the suspended dust frequency decreased from summer to spring, autumn and then winter. The results of this study can be described by considering the prevailing weather conditions and the local topography. Khanaqin is in a region neighboring the highlands and does not suffer very much from dust activity. Table 5 showed that summer and spring seasons had the highest mean frequency of suspended dust while the lowest mean frequency of dust activity was in winter. In addition, Baghdad had a much greater frequency of suspended dust activity in the central area, while Khanaqin in eastern region was the least exposed.

Table 6 indicates the mean frequency of rising dust days in the central, western and eastern regions of Iraq during all seasons. The capital city Baghdad (central region) had mean frequency of rising dust activity during the spring (5.9 days), summer ( 9.5 days), autumn ( 2.7 days) and winter (2.4) days resulting in a maximum annual average of 20.4 days. In contrast, Rutba has its maximum mean frequency of rising dust activity in spring (6.5 days). Similar to suspended dust activity, the maximum regional average frequency of rising dust activity happens in the summer season. The minimum mean frequency of rising dust activity in each season occurs at Khanaqin (eastern region) near the mountain chains along the border between Iraq and Iran. Winter had the lowest regional mean rising dust activity frequency ( 1.8 days).

Table 7 displays the mean frequency of dust storm days in the central, western and eastern regions during all seasons. Baghdad clearly had the highest mean frequency of dust storm activity during spring (about 1.3 days), with an annual mean frequency of dust storm activity on 3.1 days. Rutba had the second highest mean frequency of dust storm activity during spring (0.9 days), with 0.3 days in summer, 0.2 days in autumn and 0.3 days in winter; therefore, Rutba has the second highest annual average frequency of 1.7 days. Khanaqin had the lowest mean frequency of dust storm activity during spring ( 0.2 days) and it rarely had dust storms during summer, autumn and winter; as a result, Khanaqin had the lowest annual average frequency of only 0.3 days. The eastern region was exposed to very little dust storm activity during the 35 years. Similar to rising dust, the maximum average frequency of dust storm activity was in Baghdad compared with the other cities, especially in the summer and spring seasons. The average seasonal frequency of dust storm in Khanaqin and Rutba was less than 1 in each season, suggesting that these cities are not frequently exposed to dust storms.

\subsection{Southern Iraq}

Data from two stations have been utilized to study dust types in the southern part of Iraq (Nasiriya and Basra). Basra is a coastal city surrounded by plains and it borders the Samawa Desert, Iran, northern Kuwait and the Persian Gulf. Nasiriya is located close to the southern and Western Desert of Iraq, and it also borders the Samawa Desert. Nasiriya and Basra are situated in areas with some valleys, alluvial plains, and arid and semi-dry areas; more significantly, they are surrounded by some marshes near the rivers.

The greatest mean frequency of suspended dust activity in Nasiriya and Basra is in spring and summer compared with other periods (Table 8 ). The maximum regional average frequency of suspended dust happens in summer (14.5 days) while the minimum mean frequency occurs in winter (3.8 days). The maximum annual average frequency of suspended dust (46.1 days) is in Nasiriya. Basra had a lower annual mean suspended dust frequency of about 24.9 days.

The maximum mean frequency of rising dust days happened in summer over both Nasiriya and Basra (Table 9). The maximum regional mean frequency for rising dust activity was in summer (14.0 days), while the lowest mean frequency happened in winter (2.9 days). The maximum annual average frequency of rising dust activity was in Nasiriya (40.5 days), while a lower annual mean frequency occurred in Basra (19.8 days). Overall, there was similarity between the rising and suspended dust distributions (the regional, seasonal and annual averages).

Higher dust storm activity was observed at both southern cities compared with the northern, western and eastern regions. Nasiriya and Basra have frequently suffered from dust storm activity (Table 10). Nasiriya had a higher mean frequency of dust storm activity (4.6 days) in summer compared with Basra (about 1.1 days). The highest mean dust storm frequency is in Nasiriya during spring (2.1 days), while in Basra it was around 0.7 days. The lowest mean frequency of dust storm activity occurs in Basra during winter ( 0.2 days), while in Nasiriya it was around 0.5 days. The highest regional average frequency was about 2.9 days during the summer season and Nasiriya had a maximum annual average frequency of 7.8 days. Nasiriya and Basra are exposed to high dust activity in summer. Generally, Table 10 illustrates that this region of Iraq experienced more dust storms over the investigation 
period compared with the other regions. The annual mean frequency in the southern region was 5.0 days.

\subsection{The annual time series of the total frequency of dust events}

Figure 5 shows line graphs of the annual changes in the total frequency of dust events between 1980 and 2015 from seven meteorological stations. It shows that the time trends of all three dust events display almost similar distributions throughout the study period. According to the line graphs, there are three distinct periods of the total frequency of dust events; the first one occurred from 1983 to 1992 , the second period occurred from 1993 to 2000 and the third period occurred from 2001 to 2012. Between 1983 and 1992, there was an increase in the total frequency of dust events. The increased dust events may be related to different wars that occurred during this period, such as the Iraqi-Iranian war in 1980-1988 and the Iraq-Kuwait war in 1991. At these times, various heavy army equipment and vehicles were stationed in the dry and desert border areas between Iraq and the surrounding countries, as part of the planning and beginning of the war. Military operations and vehicle movements have led to terrestrial degradation of the surface thus increasing soil vulnerability that leads to a remarkable increase in dust mobilisation and transport in the air [38]. Between 1993 and 2000, the total frequency of dust events decreased. From 2001, the total frequency of dust events then increased. This increase may have been caused by climate change, drought and desertification phenomena [17].

\subsection{Spatial distributions of some meteorological elements}

The distribution of dust events in Iraq could be related to meteorological conditions. It is recorded throughout the year that the highest average temperatures-Temp (Fig. 6) and winds speed-WS (Fig. 7) were in the south of Iraq compared with the northern area. These two climatic elements have similar distributions throughout the year. For instance, the increased average temperatures (Fig. 6) are recorded between May and September, and then they gradually reduce between September and December. Thus, the seasonal distribution of these climatic elements could affect dust event variability during the year. For example, the seasons and regions with high temperatures and wind speeds are associated with the highest frequency of dust events in Iraq (Figs. 4, 6, and 7).

The highest frequency of dust events is recorded in the central and southern areas during summer, which relates to the period of high temperatures and wind speeds. In addition, wind speeds play an important impact in dust events by helping entrainment and transport of dust for long-range over Iraq; thus, the frequency of dust events is spread over Iraq and surrounding countries. Moreover, this is in agreement with studies by Kaskaoutis et al. [39, 40] who revealed that dust aerosols release, residence period and transfer depends on wind speeds. In general, the seasonal dust events distribution over Iraq can be related to the seasonal distribution of climatic conditions.

\section{Discussions}

According to the study results and meteorological station observations, the seasonal dust type analyses show summer and spring had the maximum frequencies of dust activity in Iraq. Thus, the study results agree with prior research of dust events [11,34], which determined that spring and summer represent the main dust season in Iraq and Middle East countries using ground observations of meteorological stations and satellite measurements. Increased temperatures in early summer over the Syrian and Iraqi deserts result in air turbulence which is probably critical for generating dust events over Iraq $[34,41]$. In addition, this study shows that the seasonal dust distribution from surface meteorology stations is consistent with the Al value distribution from TOMS and OMl satellites studied by Attiya et al. [31]. Attiya et al. [31] showed that atmospheric dust events started to increase during March-April (spring months), reaching their highest frequency through summer months (June-July) and decreasing to low values in autumn (September month). Al concentration patterns indicate larger quantities of dust aerosols above the central and southern Iraq, in comparison with the northern area, through the spring-summer seasons. The central and southern zones have more dust because of their proximity to the desert and semi-desert lands, densely populated cities, and various anthropomorphic effects; these factors lead to raised atmospheric dust storm events above Iraq and the other Middle East countries.

This research provides additional information about the spatial and temporal occurrence of dust events over Iraq. Suspended dust frequency was at a maximum in the summer season above central, southern and northern parts of Iraq, while in western Iraq the frequency of suspended dust was highest in spring. In eastern Iraq, suspended dust frequency was equal in summer and spring (2.7 days). The frequency of rising dust was highest in summer over central and southern Iraq while it was high in spring in the northern, eastern and western parts. Dust storm frequency was highest in spring in all parts except for the south where it was highest in summer. Some studies in surrounding countries analysed the monthly variation of 
Mosul city

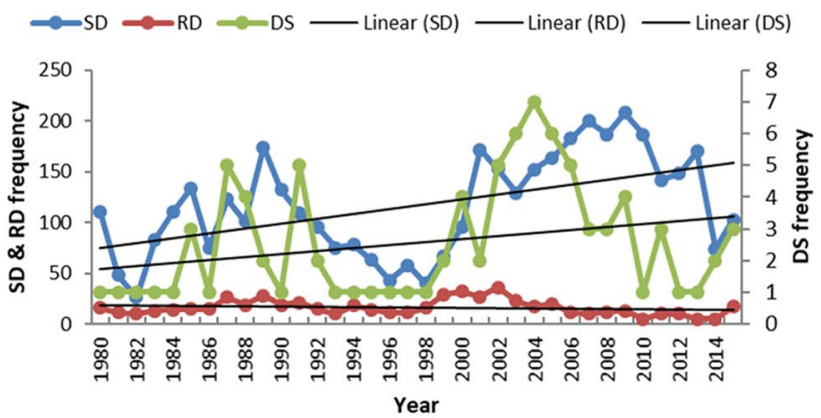

\section{Khanaqin city}

$\leadsto \mathrm{SD} \leadsto \mathrm{RD} \leadsto \mathrm{DS} \longrightarrow$ Linear (SD) - Linear (RD) - Linear (DS)

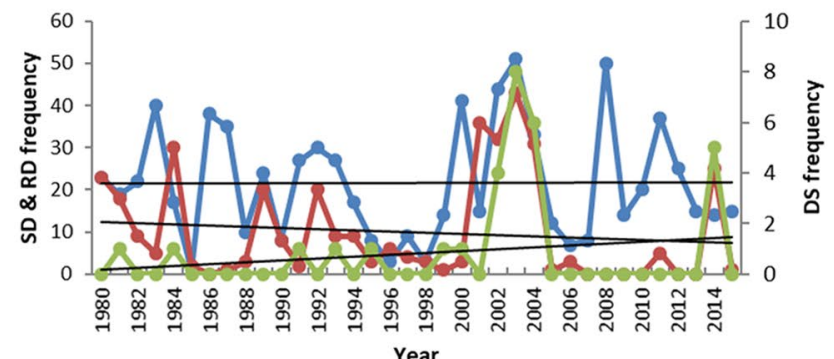

Rutba city

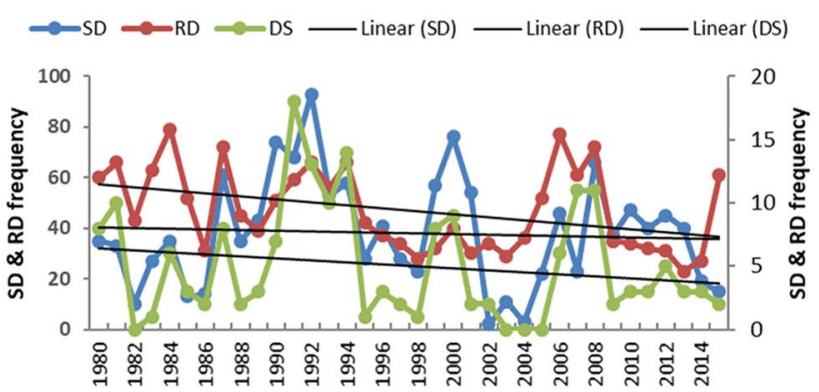

Year

Kirkuk city

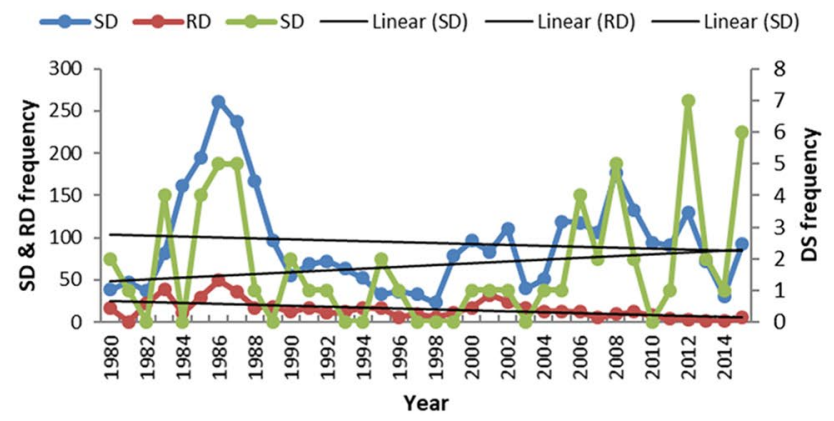

\section{Baghdad city}

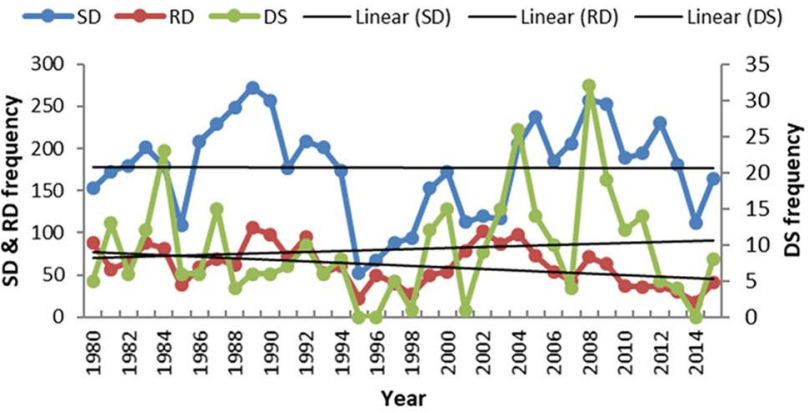

\section{Nasirya city}

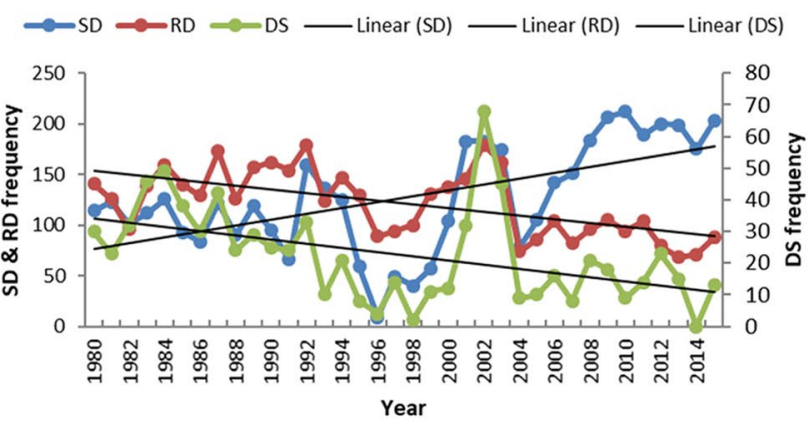

Basra city

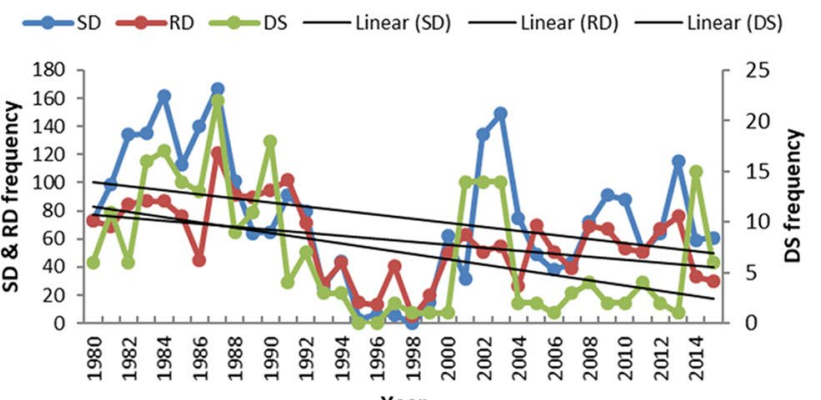

Year

Fig. 5 The annual time series of the total frequency of dust events in Iraq during 1980-2015 


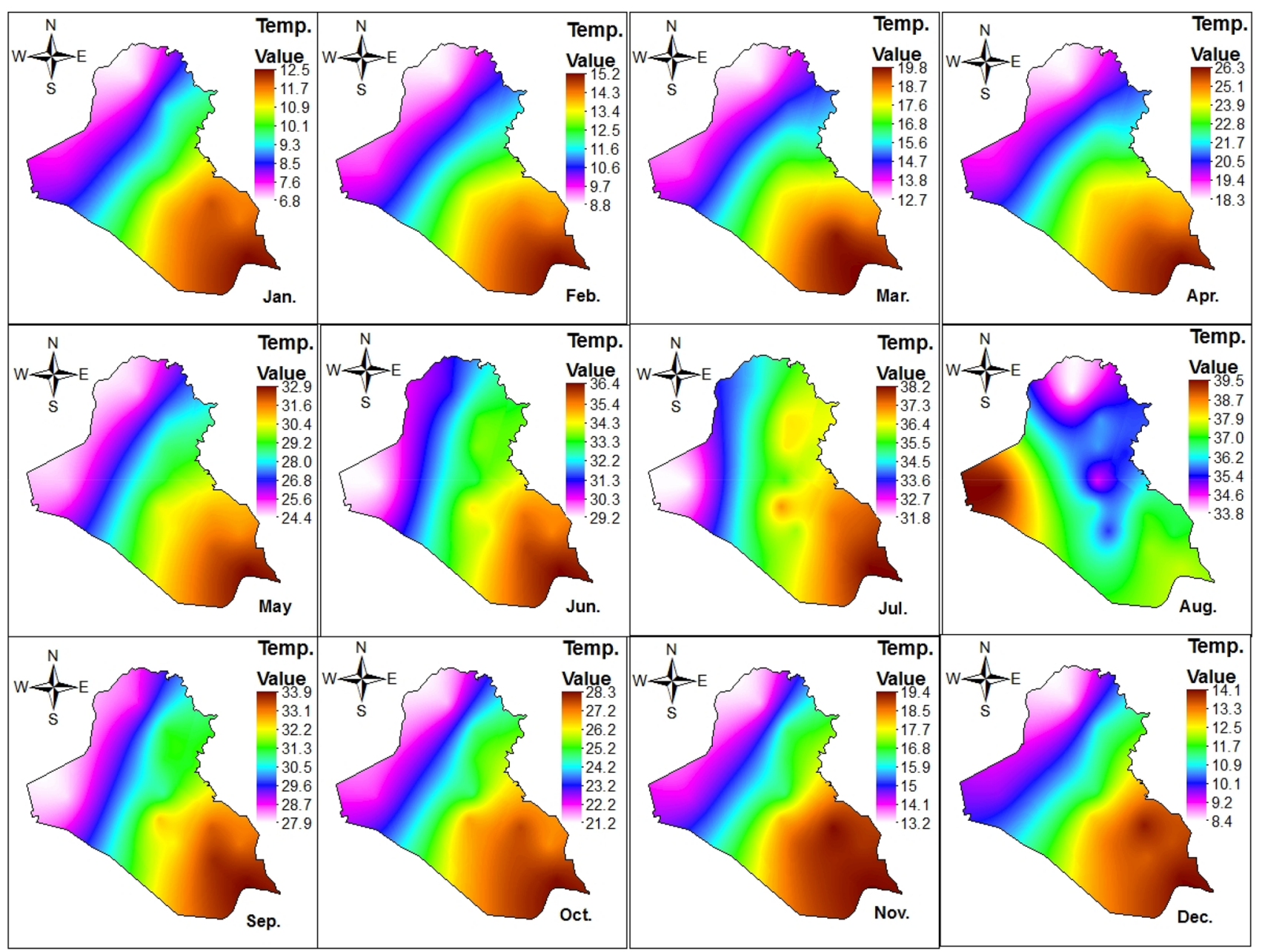

Fig. 6 The spatial distribution of monthly mean temperature between 1980 and 2015

dust events, which is in agreement with the current study. A study over Iran indicates that dust outbreaks start to increase in May, peak in July and weaken in September using the TOMS data [11]. Ghasem et al. [42] analysed dust events in southwestern Iran based on synoptic threehourly weather/dust data from twelve meteorological stations and remote sensing observations. Most dust events occurred in spring and summer while few dust events happened in autumn and winter, especially in December and January, when the atmosphere is unstable, and rainfall is likely. In the last few years, increasing dust events are associated with widespread drought periods or human factors, such as the construction of dams, agricultural activities and wars [42]. Furman [24] examined the dust sources and their temporal properties in the Middle East using synoptic data for a 21-year from 1973 to 1993 . He found that dust events recur throughout the year, but the time of maximum dust activity differs in different parts of the Middle East; dust events are more common in spring and winter in the northwestern Middle East but reach a maximum during summer months in the southwest of this region. Mashat et al. [29] recorded that annual mean number of dust events was 24.6 in southwestern Saudi Arabia, with higher average numbers of dust days in June (29.25), July (29.96) and August (30.16). Aerosol optical depth (AOD) over Kuwait city in Middle East region using ground measurements was analysed during 2008-2017. The results revealed that the elevated values of AOD from 0.75 to 2.91 are because of dust episodes, which are affecting Kuwait with an annual average frequency of about 20 days per year. The backward trajectories of air masses showed the elevated main source areas of dust affecting Kuwait significantly originated from Saudi Arabia with the contribution of the $56 \%$ and other source areas from Iraq and Iran that the contribution of $21 \%$ to the mean annual AOD [43]. Pi et al. [27] indicated considerable spatial variability of dust storm frequencies in the Xinjiang Province in northwest China, where the annual mean number of dusty days was 111.3 in the south and 10.9 in the north. 


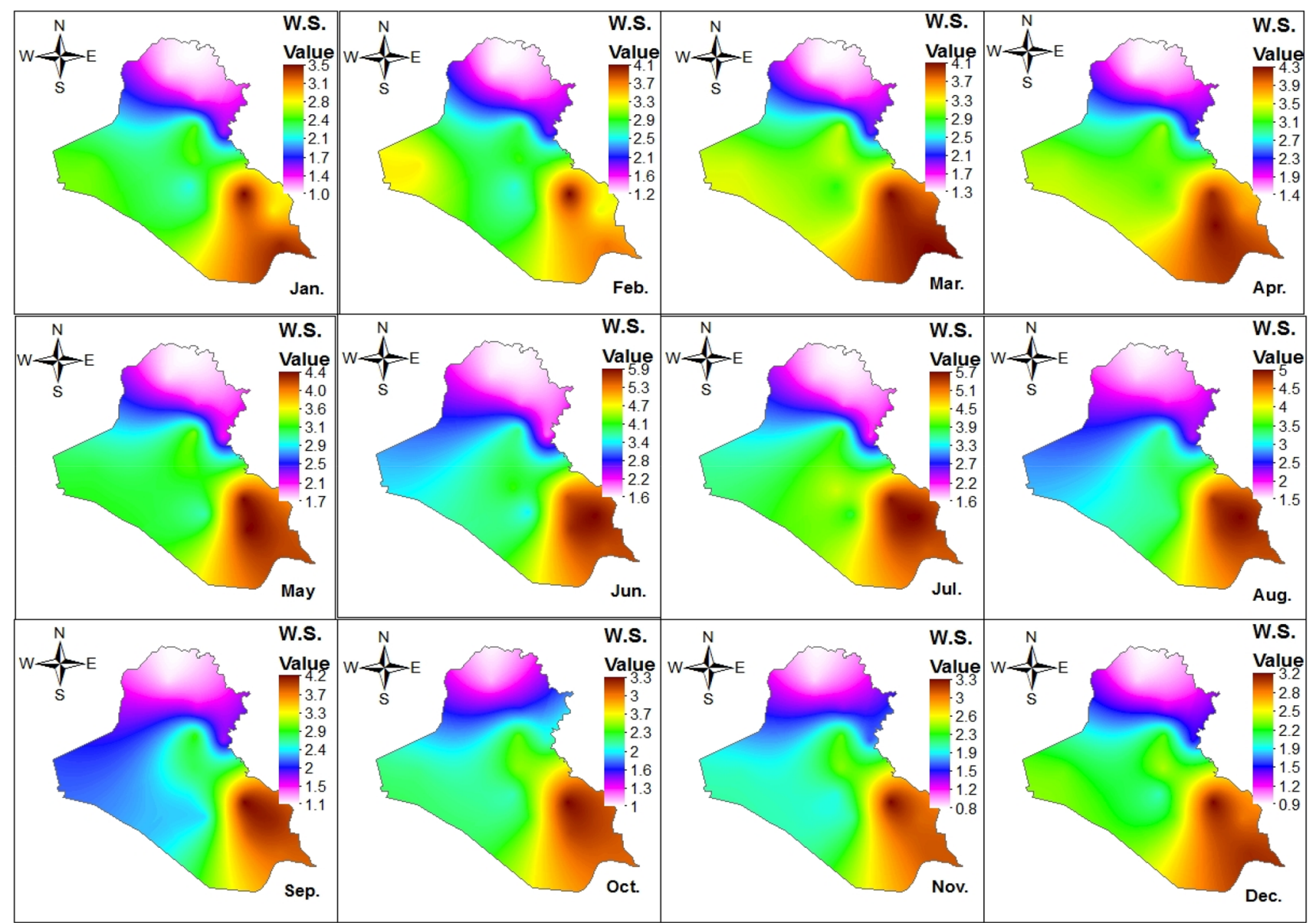

Fig. 7 The spatial distribution of monthly mean wind speed between 1980 and 2015

The spring season represents the start of the active season for dust activity, followed by increasing dust events in the summer season [34]. Dust entrainment is related to the synoptic scale weather, which consists of subtropical low air pressures that contain cold air masses moving across the Sahara towards the Mediterranean Sea and the Middle East, including Iraq. These occur in spring and result in strong surface wind speeds [37]. During summer, the interaction between the Azores High Ridge and the Indian Monsoon Low creates a strong air pressure gradient that leads to the powerful Shamal winds that play a significant role in dust storm generation in the Middle East [34, 37], especially on the Arabian Peninsula $[44,45]$. Dust activity in Iraq is influenced by intense, seasonal, frequent and continuous surface wind northwestern winds (Shamal) which produce dust storms lasting for hours or days and transport dust to adjacent areas [46]. Whereas the summer Shamal winds occur almost continuously, the winter Shamal blows two to three times monthly between December and early March [47].
In central Iraq, Baghdad had the highest frequency of suspended dust (16.1 days) in spring; the second highest was in Nasiriya in the southern region. The highest frequency of suspended dust events in summer also occurred in these two cities: Baghdad (21.1 days) and Nasiriya (18.5 days). These high-suspended dust frequencies can be explained since Nasiriya is located near the southern desert and Baghdad is located approximately $200 \mathrm{~km}$ from the Western Desert, which are probably the sources of the dust. In addition, the rising dust frequency in spring in Nasiriya and Baghdad are 11.3 and 5.9 days, respectively. The reason for the rising dust frequency being half that of the suspended dust in Baghdad may be related to the stronger local winds that are required to entrain rising dust particles. Additionally, Basra's rising dust frequency (9.8 days) was the second highest frequency during summer after Nasiriya city, these two cities are close to source areas of dust (the Southern Desert locally and arid areas in Kuwait, Saudi Arabia and Iran regionally). Nasiriya has the maximum frequency of dust storm activity (4.9 days) followed by Baghdad (1.1 days) in summer. These findings 
highlight that Baghdad, which is a significant urbanized center in Iraq, represents one of the cities that is severely influenced by dust events during the main spring and summer dust season in Iraq. Dust particle size represents a major health concern when it is inhaled into the respiratory system. Particulate matter (PM) that has a diameter less than PM10 $(10 \mu \mathrm{m})$ can lodge in the lungs while dust particles finer than PM2.5 $(2.5 \mu \mathrm{m})$ can lodge deep into the lung and can cause respiratory and cardiovascular diseases [19]. In fact, the daily average PM10 levels have increased as a result of the increased number of dust storms days in the Middle East during the past decades [3]. The increased dust events may be related to different wars that occurred during the study period, such as the Iraqi-Iranian war in 1980-1988 and the Iraq-Kuwait war in 1991. Military operations and vehicle movements in the dry and desert areas have led to terrestrial degradation of the surface thus increasing soil vulnerability that leads to a remarkable increase in dust mobilization and transport in the air [38]. This increase may also have been caused by climate change, drought and desertification phenomena [17]. The variability of dust events analysed in conjunction with meteorological data (temperature and wind speed). It was noticed that the dust events were elevated over the central and southern areas with elevated temperatures and wind speeds. The variability of the dust events over Iraq may be attributed to the seasonal differences in climatic conditions. Environment and climate changes are likely contributed elements in the occurrence of dust storms and soil erosion processes by active winds [48], particularly through the occurrence of the strong wind and increase the desiccation periods in several regions [49].

\section{Conclusions}

In this current study, analyses of annual dust events have been applied to define if there were any large changes in dust activity for the selected cities and to provide a general view of the different regions in Iraq. The spatial-temporal distribution of dust events in Iraq during 1980-2015 was analysed. The results showed more frequent events in the central and southern cities compared with the northern and eastern cities, and they also showed dust events are more common in spring and summer compared with autumn and winter during the study period. The temporal analysis of dust events in Iraq was in agreement with the temporal distribution of dust events in adjacent countries such as Iran and Saudi Arabia. Suspended dust events are more widespread and frequent compared with rising dust and dust storms in Iraq. The spatial-temporal patterns of aerosol index values from satellite have a similar distribution to dust events in Iraq.
According to the annual averages between 1980 and 2015, the cities with the maximum frequencies of dust storm activity were Nasiriya (7.8 days), Baghdad (3.1 days) and Basra (2.3 days). The findings showed that periods with considerable variability in total dust events over Iraq could be related to natural and anthropogenic influences. This analysis of dust activity has enhanced an understanding of the spatial and seasonal distribution of dust events and climate conditions in Iraq. Thus, the meteorological factors analyses are necessary to understand the climate of this region in the past, present, and future. Countries that suffer from frequent dust events in the Middle East should create climate and environment research institutions and fieldwork teams to developed methods for combating and controlling dust storms in the region and to reduce their influences and risks.

Acknowledgements The researchers are thankful for use of facilities at the University of Wollongong, Australia, and thank the Bureau of Meteorology in Iraq for supplying dust observations for this study that forms part of the first author's PhD project undertaken at the School of Earth, Atmospheric and Life Sciences at the University of Wollongong, Australia.

\section{Compliance with ethical standards}

Conflicts of interest: The authors declare no conflict of interest.

\section{References}

1. Lemaître C, Flamant C, Cuesta J, Raut J-C, Chazette P, Formenti P, Pelon J (2010) Radiative heating rates profiles associated with a springtime case of Bodélé and Sudan dust transport over West Africa. Atmos Chem Phys 10(17):8131-8150

2. WMO U (2013) Establishing a WMO sand and dust storm warning advisory and assessment system regional node for West Asia: current capabilities and needs. WMO Technical Report, 1121, 7bis, avenue de la Paix, Case postale 2300, CH-1211 Geneva 2, Switzerland

3. Goudie AS (2014) Desert dust and human health disorders. Environ Int 63:101-113

4. Gibson J (2015) Air pollution, climate change, and health. Lancet Oncol 16(6):e269

5. Kok JF, Ward DS, Mahowald NM, Evan AT (2018) Global and regional importance of the direct dust-climate feedback. Nat Commun 9(1):241

6. Dia A, Chauvel C, Bulourde M, Gérard M (2006) Eolian contribution to soils on Mount Cameroon: isotopic and trace element records. Chem Geol 226(3-4):232-252

7. Menéndez I, Diaz-Hernandez J, Mangas J, Alonso I, Sánchez-Soto P (2007) Airborne dust accumulation and soil development in the north-east sector of Gran Canaria (Canary Islands, Spain). J Arid Environ 71(1):57-81

8. Lee JA, Gill TE (2015) Multiple causes of wind erosion in the Dust Bowl. Aeol Res 19:15-36

9. Meibodi AE, Abdoli G, Taklif A, Morshedi B (2015) Economic modeling of the regional polices to combat dust phenomenon by using game theory. Procedia Economics and Finance 24:409-418 
10. Ginoux P, Prospero JM, Gill TE, Hsu NC, Zhao M (2012) Globalscale attribution of anthropogenic and natural dust sources and their emission rates based on MODIS Deep Blue aerosol products. Rev Geophys 50(3):1-36

11. Prospero JM, Ginoux P, Torres O, Nicholson SE, Gill TE (2002) Environmental characterization of global sources of atmospheric soil dust identified with the Nimbus 7 Total Ozone Mapping Spectrometer (TOMS) absorbing aerosol product. Rev Geophys 40(1):1-31

12. Tegen I, Fung I (1994) Modeling of mineral dust in the atmosphere: Sources, transport, and optical thickness. J Geophys Res Atmos 99(D11):22897-22914

13. Bryant RG (2013) Recent advances in our understanding of dust source emission processes. Prog Phys Geogr 37(3):397-421

14. Wang H, Jia X, Li K, Li Y (2015) Horizontal wind erosion flux and potential dust emission in arid and semiarid regions of China: a major source area for East Asia dust storms. CATENA 133:373-384

15. D'Odorico P, Bhattachan A, Davis KF, Ravi S, Runyan CW (2013) Global desertification: drivers and feedbacks. Adv Water Resour 51:326-344

16. Elmore A, Kaste J, Okin G, Fantle M (2008) Groundwater influences on atmospheric dust generation in deserts. J Arid Environ 72(10):1753-1765

17. Notaro M, Yu Y, Kalashnikova OV (2015) Regime shift in Arabian dust activity, triggered by persistent Fertile Crescent drought. J Geophys Res Atmos 120(19):10-229

18. Zoljoodi M, Didevarasl A, Saadatabadi AR (2013) Dust events in the western parts of Iran and the relationship with drought expansion over the dust-source areas in Iraq and Syria. Atmos Clim Sci 3(3):321-336

19. Middleton N (2017) Desert dust hazards: a global review. Aeol Res 24:53-63

20. Hsu N, Gautam R, Sayer A, Bettenhausen C, Li C, Jeong M, Tsay S, Holben B (2012) Global and regional trends of aerosol optical depth over land and ocean using SeaWiFS measurements from 1997 to 2010.

21. Irino T, Tada R (2000) Quantification of aeolian dust (Kosa) contribution to the Japan Sea sediments and its variation during the last 200 ky. Geochem J 34(1):59-93

22. Guan Q, Yang J, Zhao S, Pan B, Liu C, Zhang D, Wu T (2015) Climatological analysis of dust storms in the area surrounding the Tengger Desert during 1960-2007. Clim Dyn 45(3-4):903-913

23. Orlovsky N, Orlovsky L, Indoitu R (2013) Severe dust storms in Central Asia. Arid ecosystems 3(4):227-234

24. Furman HKH (2003) Dust storms in the Middle East: sources of origin and their temporal characteristics. Indoor Built Environ 12(6):419-426

25. Wang X, Huang J, Ji M, Higuchi K (2008) Variability of East Asia dust events and their long-term trend. Atmos Environ 42(13):3156-3165

26. Kang L, Huang J, Chen S, Wang X (2016) Long-term trends of dust events over Tibetan Plateau during 1961-2010. Atmos Environ 125:188-198

27. Pi H, Sharratt B, Lei J (2017) Atmospheric dust events in central Asia: relationship to wind, soil type, and land use. J Geophys Res Atmos 122(12):6652-6671

28. Rezazadeh M, Irannejad P, Shao Y (2013) Climatology of the Middle East dust events. Aeol Res 10:103-109

29. Mashat A-WS, Alamoudi AO, Awad AM, Assiri ME (2017) Synoptic characteristics of dusty spring days over central and eastern Saudi Arabia. Air Qual Atmos Health 10(3):307-323

30. Pokharel AK, Kaplan ML (2017) Dust Climatology of the NASA Dryden Flight Research Center (DFRC) in Lancaster, California, USA. Climate 5(1):15
31. Attiya AA, Jones BG, Marx S (2018) Spatial-temporal analysis of Aerosol Index (AI) distribution and some climatic factors: case study from Iraq, 1980-2015. Model Earth Syst Environ 5(1):203-216

32. Shao Y (2008) Physics and modelling of wind erosion, vol 37. Springer, Berlin

33. Shao Y, Dong C (2006) A review on East Asian dust storm climate, modelling and monitoring. Global Planet Change 52(1-4):1-22

34. Middleton N (1986) Dust storms in the Middle East. J Arid Environ 10:82-96

35. Varoujan KS, Nadhir A-A, Sven K (2013) Sand and dust storm events in Iraq. Nat Sci 5(10):1084-1094

36. Hasanean H (2004) Middle east meteorology. https://www.eolss net/. Accessed 7 Aug 2015

37. Hamidi M, Kavianpour MR, Shao Y (2013) Synoptic analysis of dust storms in the Middle East. Asia Pac J Atmos Sci 49(3):279-286

38. El-Shobokshy MS, Al-Saedi YG (1993) The impact of the gulf war on the Arabian environment-I. Particulate pollution and reduction of solar irradiance. Atmos Environ Part A 27(1):95-108

39. Kaskaoutis D, Kambezidis H, Nastos P, Kosmopoulos P (2008) Study on an intense dust storm over Greece. Atmos Environ 42(29):6884-6896

40. Kaskaoutis D, Nastos P, Kosmopoulos P, Kambezidis H, Kharol SK, Badarinath K (2010) The Aura-OMI Aerosol Index distribution over Greece. Atmos Res 98(1):28-39

41. Abdi Vishkaee F, Flamant C, Cuesta J, Flamant P, Khalesifard HR (2011) Multiplatform observations of dust vertical distribution during transport over northwest Iran in the summertime. J Geophys Res Atmos 116(D5):1-13

42. Ghasem A, Shamsipour A, Miri M, Safarrad T (2012) Synoptic and remote sensing analysis of dust events in southwestern Iran. Nat Hazards 64(2):1625-1638

43. Kokkalis $\mathrm{P}$, AlJassar HK, Solomos $\mathrm{S}$, Raptis $\mathrm{P}-\mathrm{I}$, AlHendi $\mathrm{H}$, Amiridis V, Papayannis A, AISarraf H, AIDimashki M (2018) Long-term ground-based measurements of aerosol optical depth over Kuwait City. Remote Sens 10(11):1807

44. Yu Y, Notaro M, Liu Z, Wang F, Alkolibi F, Fadda E, Bakhrjy F (2015) Climatic controls on the interannual to decadal variability in Saudi Arabian dust activity: toward the development of a seasonal dust prediction model. J Geophys Res Atmos 120(5):1739-1758

45. Yu Y, Notaro M, Liu Z, Kalashnikova O, Alkolibi F, Fadda E, Bakhrjy F (2013) Assessing temporal and spatial variations in atmospheric dust over Saudi Arabia through satellite, radiometric, and station data. J Geophys Res Atmos 118 (23):13,253-213, 264

46. Sissakian V, Al-Ansari N, Knutsson S (2013) Sand and dust storm events in Iraq. J Nat Sci 5(10):1084-1094

47. Rao PG, Al-Sulaiti M, Al-Mulla AH (2001) Winter Shamals in Qatar. Arabian Gulf Weather 56(12):444-451

48. Lavell A, Oppenheimer M, Diop C, Hess J, Lempert R, Li J, Myeong $S$ (2012) Managing the risks of extreme events and disasters to advance climate change adaptation. A Special Report of Working Groups I and II of the Intergovernmental Panel on Climate Change (IPCC):25-64

49. Dai $A$ (2011) Drought under global warming: a review. Wiley Interdisciplinary Reviews. Clim Change 2(1):45-65

Publisher's Note Springer Nature remains neutral with regard to jurisdictional claims in published maps and institutional affiliations. 